\title{
Mitral valve abnormalities identified by cardiovascular magnetic resonance represent a primary phenotypic expression of hypertrophic cardiomyopathy
}

\author{
Martin S Maron*1, Caitlin Harrigan'1, Iacopo Olivotto ${ }^{2}$, Evan Appelbaum³, C \\ Michael Gibson ${ }^{3}$, John Lesser ${ }^{4}$, Tammy Haas ${ }^{4}$, James Udelson ${ }^{1}$, \\ Warren Manning ${ }^{3}$ and Barry Maron ${ }^{4}$
}

\begin{abstract}
Address: ${ }^{1}$ Tufts Medical Center, Boston, MA, USA, ${ }^{2}$ Azienda Ospedadiera Unversiteria Careggi, Florence, Italy, ${ }^{3}$ Beth Israel Deaconess medical center, Boston, MA, USA and ${ }^{4}$ Minneapolis Heart Institute Foundation, Minneapolis, MN, USA

* Corresponding author
\end{abstract}

from 13th Annual SCMR Scientific Sessions

Phoenix, AZ, USA. 21-24 January 2010

Published: 21 January 2010

Journal of Cardiovascular Magnetic Resonance 2010, I 2(SuppI I):PI87 doi:I0.I I86/I532-429X-I2-SI-PI87

This abstract is available from: http://jcmr-online.com/content/I2/SI/PI87

(c) 2010 Maron et al; licensee BioMed Central Ltd.

\section{Introduction}

Hypertrophic cardiomyopathy (HCM) is a genetic heart disease characterized by left ventricular (LV) hypertrophy due to mutations in 11 genes encoding proteins of the sarcomere. Whether a primary abnormality of the mitral valve is part of this disease process is unresolved.

\section{Purpose}

We have applied cardiovascular magnetic resonance (CMR) with its high spatial and temporal resolution, to characterize mitral valve morphology in a large HCM population.

\section{Methods}

Cine CMR images were obtained in 224 HCM subjects ( 42 \pm 18 years; $71 \%$ male) and 70 normal control subjects ( 41 \pm 17 years; $69 \%$ male). ECG-gated, breath-hold cines were obtained in the 3-chamber cine view $(3 \mathrm{CV})$ and in contiguous $10 \mathrm{~mm}$ thick short-axis slices achieving complete coverage of the LV. Anterior mitral leaflet (AML) and posterior mitral leaflet (PML) lengths were manually measured at end-diastole in the $3 \mathrm{CV}$ when the leaflets were fully extended parallel to the anterior septum and anterolateral wall.

\section{Results}

The AML and PML lengths were greater in HCM patients compared to controls $(26 \pm 4 \mathrm{~mm}$ vs. $20 \pm 4 \mathrm{~mm}$; P < 0.001 and $14 \pm 4 \mathrm{~mm}$ vs. $11 \pm 3 \mathrm{~mm} ; \mathrm{P}<0.001$, respectively), including $24(10 \%)$ with substantially increased AML length of $\geq 32 \mathrm{~mm}$ ( $\geq 3 \mathrm{SD}$ above control). AML and PML lengths measured in vivo by CMR did not differ significantly from that previously reported valves removed at surgery or postmortem $(p=N S)$.

Although AML length was longer in male patients $(26 \pm 4$ $\mathrm{mm}$ vs. $25 \pm 4 \mathrm{~mm}$ in females, $\mathrm{p}=0.04$ ) there was no difference with respect to age, so that HCM patients $\leq 16$ years of age had similar leaflet lengths to those $\geq 65$ years ( $23 \pm 5 \mathrm{~mm}$ vs. $26 \pm 3 \mathrm{~mm} ; \mathrm{p}=0.05)$. In addition, there was no difference in AML length in HCM patients with or without LV outflow obstruction ( $27 \pm 4$ vs. $26 \pm 5 \mathrm{~mm}$; $=0.10)$, nor between AML length and maximum LV wall thickness $(\mathrm{R}=0.11 ; \mathrm{p}=0.09)$ or total $\mathrm{LV}$ mass $(\mathrm{R}=0.72$; $\mathrm{p}=0.3$ ). Specifically, in HCM patients with only limited hypertrophy (13-19 mm), 31 patients (14\%) had AML lengths which were greatly increased ( $\geq 2$ SD above controls). 


\section{Conclusion}

CMR provides an accurate in vivo assessment of mitral valve leaflets lengths, which are increased in HCM patients, unrelated to other clinical and demographic variables, including age and magnitude of LV hypertrophy. These findings suggest that in addition to LV hypertrophy, enlargement of the mitral valve is likely part of the primary phenotypic expression of HCM.

Publish with Bio Med Central and every scientist can read your work free of charge

"BioMed Central will be the most significant development for disseminating the results of biomedical research in our lifetime. " Sir Paul Nurse, Cancer Research UK

Your research papers will be:

- available free of charge to the entire biomedical community

- peer reviewed and published immediately upon acceptance

- cited in PubMed and archived on PubMed Central

- yours - you keep the copyright 